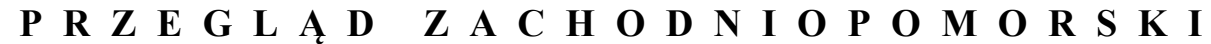 ROCZNIK XXXV (LXIV) ROK 2020 ZESZYT 3
}

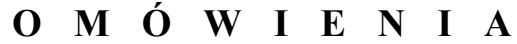

\author{
MACIEJ WóJCIK \\ ORCID: 0000-0001-8754-0816 \\ Uniwersytet Szczeciński \\ e-mail: wojcikmacio@gmail.com
}

\section{TOMASZ SIKORSKI, PREKURSORZY ZIELONEGO ANARCHIZMU. La Belle EPoque, TORUŃ: WydAWNictwo AdAM MARSZAŁEK, 2020, SS. 378}

Anarchizm nadal należy do grona ideologii, doktryn politycznych, filozofii umykających szerokiemu zainteresowaniu polskich badaczy, na rzecz klasycznych nurtów myśli politycznej. Oczywiście tematyka związana z szeroko rozumianym ruchem anarchistowskim nie jest całkowicie ignorowana, o czym świadczą m.in. starsze i nowe publikacje, często o różnej wartości merytorycznej (np. Anarchizm [źródta, jego twórcy, metody walki] Wincentego Kołodzieja ${ }^{1}$, Ruchy i myśl polityczna syndykalizmu w Polsce Rafała Chwedoruka ${ }^{2}$, liczne publikacje Radosława Antonowa $^{3}$, Pawła Malendowicza ${ }^{4}$ i Piotra Laskowskiego ${ }^{5}$ ), konferencje poświęcone historii polskiego (i nie tylko) anarchizmu (cykl konferencji „Z dziejów anarchizmu”: „Z dziejów polskiego anarchizmu”, Pobierowo 2010, „Z dziejów anarchizmu. W dwusetlecie urodzin Michaiła Bakunina”, Szczecin 2014, „Z dziejów

1 Wincenty Kołodziej, Anarchizm (źródła, jego twórcy, metody walki) (Toruń: Wydawnictwo Adam Marszałek, 2000).

2 Rafał Chwedoruk, Ruchy i myśl polityczna syndykalizmu w Polsce (Warszawa: Elipsa, 2011).

3 M.in. Radosław Antonów, Pod czarnym sztandarem: anarchizm w Polsce po 1980 roku (Wrocław: Uniwersytet Wrocławski, 2004) czy ostatnio: tegoż, Anarchizm cafe racer (Syców: Diligentia, 2017).

4 Paweł Malendowicz, Polski ruch anarchistyczny wobec wspótczesnych wyzwań politycznych (Piła: Państwowa Wyższa Szkoła Zawodowa, 2007).

5 Piotr Laskowski, Szkice z dziejów anarchizmu (Warszawa: Muza, 2006). 
anarchizmu. W 80-lecie wybuchu wojny domowej w Hiszpanii”, Szczecin 2016) oraz działalność poznańskiej Oficyny Wydawniczej Bractwa „Trójka”, zajmującej się w głównej mierze publikacją prac, broszur o popularyzatorskim charakterze, dotyczących historii anarchizmu oraz pokrewnych ruchów społecznych i ideologii. Jednakże wszystkie wymienione wcześniej inicjatywy oraz opracowania stanowią jedynie niewielką część możliwości związanych z odkrywaniem kolejnych nieznanych kart anarchistycznej historiografii, związanej z dziejami Polski i innych państw.

Klasyczne odmiany i nurty anarchizmu (anarchosyndykalizm, anarchokomunizm, anarchokolektywizm, anarchoindywidualizm) są poddawane naukowej krytyce, badaniom i dyskusjom, lecz, niestety, inne „odcienie” myśli anarchistowskiej nadal nie stały się dostrzegalnym obiektem zainteresowań szerokiego grona badaczy, lub też zostały jedynie połowicznie wspominane w opracowaniach dotyczących klasycznego anarchizmu. Do odmian anarchizmu leżących często poza zasięgiem zainteresowania możemy zaliczyć m.in.: anarchoegzystencjalizm, anarchopacyfizm, anarchonacjonalizm, a przede wszystkim tzw. zielony anarchizm. Zielony anarchizm możemy określić pewnym zbiorem myśli, stylów życia, światopoglądów wywodzących się z anarchizmu i dzielących z nim główne wartości (wolność jako najwyższa wartość, krytyka kapitalistycznych stosunków), opartych na głębokiej myśli ekologicznej, które ostatnimi czasy przeżywają odrodzenie wynikające z działalności pewnych grup i organizacji (np. Greenpeace, The Ocean Cleanup) oraz jednostek ludzkich (Murray Bookchin, Peter Singer, Dow Chenin, Bob Brown). Można odnieść wrażenie, że zielony anarchizm w sferze społecznego aktywizmu przeżywa dzisiaj swój renesans, którego przyczynę stanowią coraz częstsze i większe katastrofy ekologiczne, szybka i ekspansywna urbanizacja wymagająca redukcji naturalnych terenów oraz coraz bardziej popularny ruch wyzwolenia zwierząt, znajdujący wielu zwolenników niemalże na wszystkich kontynentach, nierozerwalnie związany $\mathrm{z}$ wegetarianizmem, weganizmem czy frutarianizmem. Współcześni przedstawiciele szkół zielonego anarchizmu oskarżają o powodowanie kryzysów ekologicznych korporacje mające ściśle współpracować z państwowymi rządami, również czerpiącymi pieniężne zyski z destrukcyjnych wycinek terenów zielonych, przemysłowej hodowli zwierząt i wytwarzania substancji zanieczyszczających środowisko, stanowiących efekt uboczny produkcji towarów niezbędnych dla wielu gałęzi gospodarki. Nie dziwi więc fakt, że współcześni działacze ekologiczni i radykalni 
przyrodnicy stają się, świadomie bądź nie, krytykami współczesnych relacji na linii społeczeństwo-władza, cywilizacji, struktur i instytucji państwowych.

Trzeba pamiętać, że myśl zielonego anarchizmu nie jest odkryciem współczesności, a jest ona głęboko osadzona w zamierzchłej przeszłości i jej twórców możemy odnaleźć już wśród myślicieli żyjących w XVIII wieku. Anarchizm związany z głębokim szacunkiem do otaczającej człowieka natury i propagowaniem harmonijnego życia zgodnego $\mathrm{z}$ nastającymi kolejno po sobie porami roku, nie był zbyt popularny wśród polskich działaczy anarchistycznych, choć z pewnością byli oni zaznajomieni z przemyśleniami i pracami swoich zagranicznych towarzyszy i dawnych mentorów.

Polski rynek wydawniczy nie obfituje niestety w publikacje dotyczące historii zielonego anarchizmu. Dla polskiego czytelnika w większości dostępne są jedynie krótkie opracowania popularnonaukowe, skupiające się na spuściźnie skromnej części reprezentantów tej bardzo ciekawej szkoły anarchizmu. Jednym z najbardziej znanych w Polsce „zielonych anarchistów” jest Amerykanin Henry David Thoreau, bowiem najwięcej prac poświęconych, nazwijmy to umownie radykalnej ekologii, wydanych w Polsce, traktuje o życiu i spuściźnie pisarza i myśliciela związanego ze środowiskiem amerykańskich transcendentalistów. Ową tematyczną niszę na polskim rynku wydawniczym uzupełniła wydana w marcu tego roku książka autorstwa Tomasza Sikorskiego Prekursorzy zielonego anarchizmu. Praca poświęcona jest ludziom żyjącym od XVIII do XX wieku, którzy w mniejszym bądź większym stopniu zapoczątkowali powstanie lub rozwój myśli anarchizmu ekologicznego. Autor w poszczególnych rozdziałach skupia się na myślicielach, aktywistach, pisarzach, którzy mogą być całkowicie identyfikowani z anarchizmem zbudowanym na podstawach głębokiej ekologii, powrotem do przedindustrialnego trybu życia, albo takich, dla których dbałość o środowisko naturalne, sprzeciw wobec mechanizacji wszystkich sfer życia, poszanowanie dla istnienia przedstawicieli fauny i flory, stanowiło tylko pewne elementy o wiele szerszych i bardziej skomplikowanych koncepcji wymierzonych przeciwko elitaryzmowi i niesprawiedliwości społecznej.

Praca profesora Sikorskiego składa się z biogramów przedstawicieli opisywanego nurtu, bowiem życiowe koleje ekscentrycznych ekologów i burzycieli zastanych norm społecznych i prawnych najpełniej ukazują wartości, zasady i cele, jakie stały u podstaw ideologii i życiowych filozofii współtworzących ekologiczny anarchizm. Dlatego też poszczególne rozdziały opracowania zawierają również objaśnienia takich terminów, jak: anarchoprymitywizm, anarchoweganizm, 
anarchowegetarianizm, anarchonaturyzm, bioregionazlim, biocentryzm, bowiem ich znajomość jest niezbędna do kompletnego zrozumienia spuścizny prekursorów zielonego anarchizmu. Autor, przedstawiając życiorysy takich osobistości, jak Lew Tołstoj, Elise Reclus, Henry David Thoreau, Henri Gabriel Zisly, William Godwin, Louis Rimbault, posiłkuje się bardzo często obszernymi cytatami prac (książek, artykułów, esejów, powieści), które wyszyły spod pióra wyżej wymienionych myślicieli. Przytaczane fragmenty ich najważniejszych, najbardziej reprezentatywnych tekstów, wraz z bogatą bibliografią, mogą wspomóc dociekliwego czytelnika w dalszych poszukiwaniach. Na marginesie można dodać, że część z tych prac nigdy nie była tłumaczona na język polski.

Należy zaznaczyć, że Prekursorzy zielonego anarchizmu, mimo bogatej bibliografii oraz dodatku w postaci wykazu wolnościowych, ekologicznych kolonii powstałych niegdyś na różnych kontynentach, nie są całościowym kompendium informacji dotyczącym omawianego ruchu. Książka Tomasz Sikorskiego tak naprawdę stanowi szerokie rozeznanie w nurcie myśli politycznej pomijanej i być może niedocenianej przez środowiska naukowe. Opracowanie to jest swoistym kompasem, drogowskazem zarówno dla osób zainteresowanych historią idei i myśli politycznej mającej nadal wpływ na niektóre współczesne ruchy, jak i dla naukowców poszukujących inspiracji do podjęcia kolejnych badań. Treść tej bardzo ciekawej pracy nie wyczerpuje szerokiej tematyki związanej z losami ojców idei zielonego anarchizmu i ich kontynuatorów, zmusza do refleksji, mogących stanowić przyczynek do opracowania problemów, zagadnień orbitujących wokół owego tematu, takich jak stosunek polskich działaczy anarchistycznych na przestrzeni lat do ekologii i ochrony środowiska naturalnego, obecność tekstów autorstwa przedstawicieli anarchizmu ekologicznego w polskiej prasie anarchistycznej, czy korelacja pomiędzy radykalną krytyką kapitalizmu a głoszeniem haseł nawołujących do odnowienia kontaktów człowieka z Matką Naturą. 


\section{Bibliografia}

Antonów, Radosław. Anarchizm cafe racer. Syców: Diligentia, 2017.

Antonów, Radosław. Pod czarnym sztandarem: anarchizm w Polsce po 1980 roku. Wrocław: Uniwersytet Wrocławski, 2004.

Chwedoruk, Rafał. Ruchy i myśl polityczna syndykalizmu w Polsce. Warszawa: Elipsa, 2011.

Kołodziej, Wincenty. Anarchizm (źródła, jego twórcy, metody walki). Toruń: Wydawnictwo Adam Marszałek, 2000.

Laskowski, Piotr. Szkice z dziejów anarchizmu. Warszawa: Muza, 2006.

Malendowicz, Paweł. Polski ruch anarchistyczny wobec współczesnych wyzwań politycznych. Piła: Państwowa Wyższa Szkoła Zawodowa, 2007. 